Literacy in the United States 
This page intentionally left blank 


\section{Literacy in the United States}

Readers and Reading since 1880

\section{Carl F. Kaestle}

Helen Damon-Moore, Lawrence C.

Stedman, Katherine Tinsley, and William Vance Trollinger, Jr.

Yale University Press

New Haven and London 
Published with assistance from the Louis Stern Memorial Fund.

Copyright $\odot 1991$ by Yale University. All rights reserved.

This book may not be reproduced, in whole or in part, including illustrations, in any form (beyond that copying permitted by Sections 107 and 108 of the U.S. Copyright Law and except by reviewers for the public press), without written permission from the publishers.

Designed by James J. Johnson.

Set in Century Schoolbook type by The Composing Room of Michigan, Inc.

Printed in the United States of America

The paper in this book meets the guidelines for permanence and durability of the Committee on Production Guidelines for Book Longevity of the Council on Library Resources.
Library of Congress Cataloging-inPublication Data

Kaestle, Carl F.

Literacy in the United States : readers and reading since 1880 / Carl F. Kaestle ; Helen DamonMoore ... [et al.]. p. $\mathbf{c m}$.

Includes bibliographical references (p. ) and index.

ISBN 978-0-300-05430-9

1. Literacy-United States-

History. I. Damon-Moore, Helen

(Helen M.) II. Title.

LC151.K32 1991

$302.2^{\prime} 244-\mathrm{dc} 20$

90-46716

CIP

A catalogue record for this book is available from the British Library. 
I N M MOR Y O F

Lawrence A. Cremin

Scholar, teacher, and friend 
This page intentionally left blank 